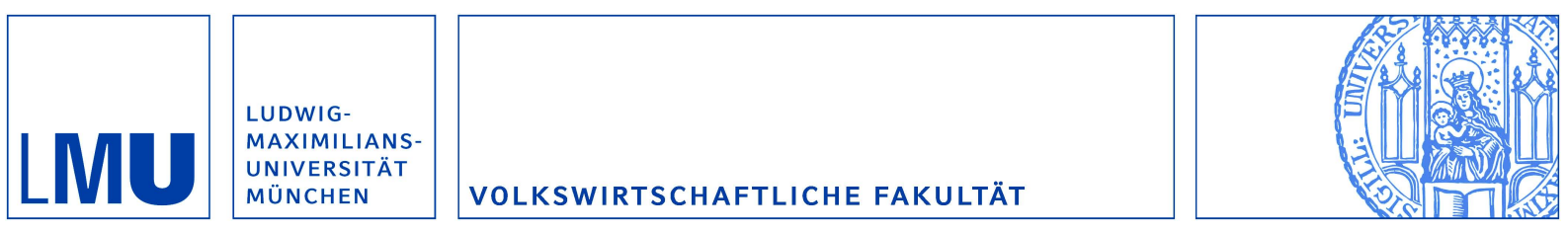

Haufler, Andreas and Wooton, lan:

Cross-border banking in regulated markets: Is financial integration desirable?

Munich Discussion Paper No. 2016-15

Department of Economics

University of Munich

Volkswirtschaftliche Fakultät

Ludwig-Maximilians-Universität München

Online at https://doi.org/10.5282/ubm/epub.29657 


\title{
Cross-border banking in regulated markets: Is financial integration desirable? ${ }^{1}$
}

\author{
Andreas Haufler ${ }^{2}$ \\ University of Munich and CESifo \\ Ian Wooton ${ }^{3}$ \\ University of Strathclyde, CEPR and CESifo
}

October 2016

${ }^{1}$ Previous versions of this paper were presented, under the title "Capital regulation and trade in banking services", at conferences and seminars in Bari, Beijing, Glasgow, Indianapolis, Lugano, Munich, Münster and Zurich. We thank conference participants and in particular Tim Goodspeed, Hendrik Hakenes, Ben Lockwood and Bernd Rudolph for helpful comments. This paper was started when Andreas Haufler visited Strathclyde University and continued when Ian Wooton was at the Center for Economic Studies in Munich. We thank both institutions for their hospitality. Andreas Haufler acknowledges financial support from the German Research Foundation (Grant No. HA3195/9-1).

${ }^{2}$ Seminar for Economic Policy, Akademiestraße 1, D-80799 Munich, Germany; e-mail: Andreas.Haufler@econ.lmu.de

${ }^{3}$ Department of Economics, Strathclyde Business School, 199 Cathedral Street, Glasgow G4 0QU, United Kingdom; e-mail: ian.wooton@strath.ac.uk 


\begin{abstract}
We set up a two-country, regional model of trade in financial services. Competitive firms in each country manufacture untraded consumer goods in an uncertain productive environment, borrowing funds from a bank in either the home or the foreign market. Duopolistic banks can choose their levels of monitoring of firms and thus the levels of risk-taking, where the risk of bank failure is partly borne by taxpayers in the banks' home countries. Moreover, each bank chooses the share of its lending allocated between domestic and foreign firms, but the bank's overall loan volume is fixed by a capital requirement set optimally in its home country. In this setting we consider two types of financial integration. A reduction in the transaction costs of cross-border banking reduces aggregate output and increases risk-taking, thus harming consumers and taxpayers in both countries. In contrast, a reduction in the costs of screening foreign firms is likely to be beneficial for banks, consumers, and taxpayers alike.
\end{abstract}

Keywords: cross-border banking, capital regulation, financial integration JEL classifications: F36, G18, H81 


\section{Introduction}

International trade in banking services has increased rapidly over the last few decades, and in particular during the past 15 years. Total international bank lending accelerated sharply after 2000, almost quadrupling between 2000 and 2008, by which point it had reached $40 \%$ of world GDP. Since then, cross-border banking has receded noticeably, but the worldwide volume of cross-border claims is still more than twice what it was in 2000 (see Figure 1). ${ }^{1}$ More disaggregated evidence comes from a database with more than 5000 banks in 137 countries (Claessens and van Horen, 2014). This documents large increases in the presence of foreign banks in most countries since the mid-1990s, but also a substantial heterogeneity at the country level with respect to the importance of foreign banks in national banking sectors.

Figure 1: Worldwide cross-border claims of banking sectors (1980-2016)

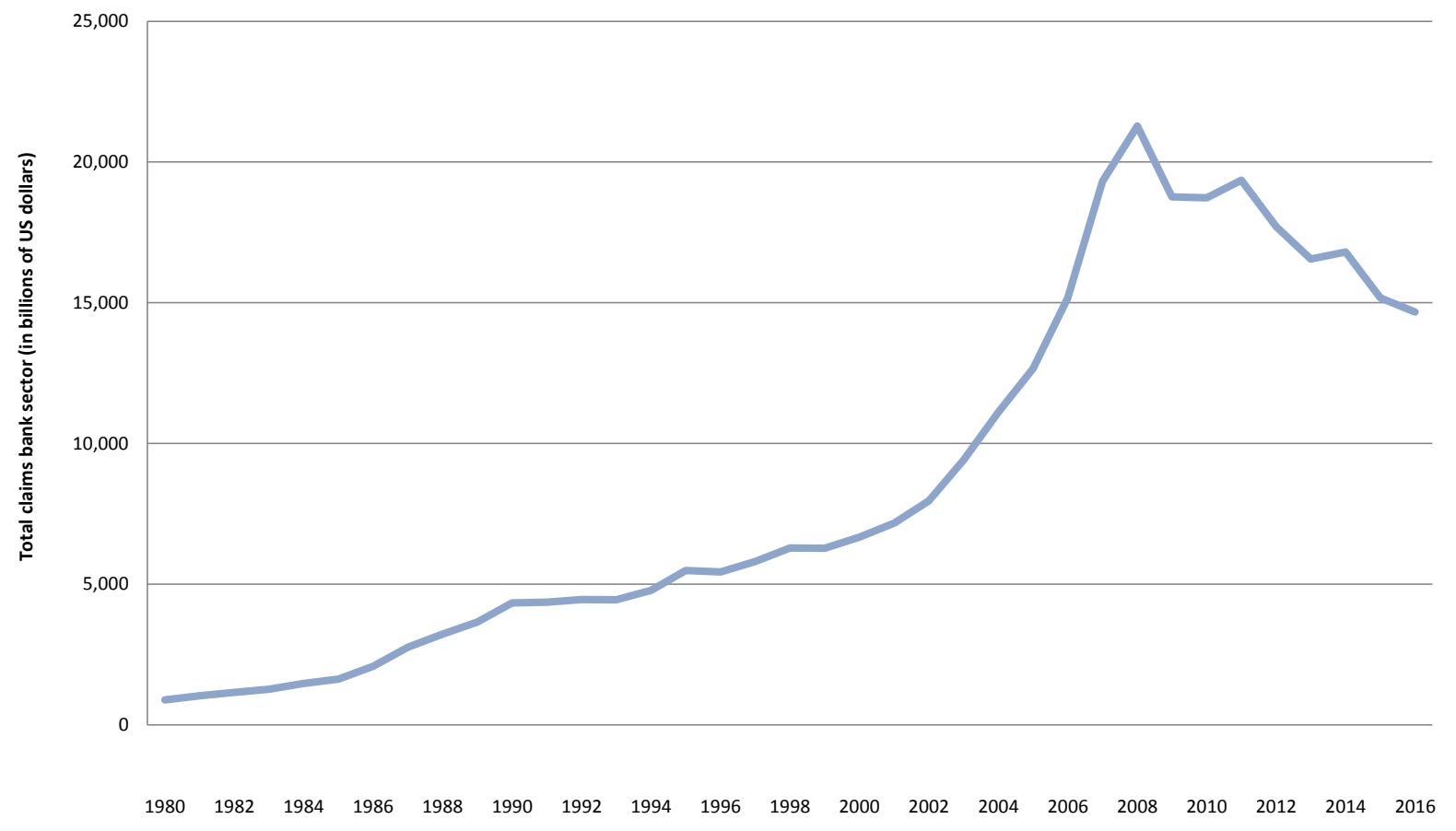

Source: BIS Statistics (2016), Table A4.1, stats.bis.org/statx/srs/table/a4.1

The financial crisis of 2008 has shown that this increasing internationalization in the banking sector is not without risk. Many banks worldwide have suffered huge losses

\footnotetext{
${ }^{1}$ For more details, see Committee on the Global Financial System (2010), Graph 1.
} 
from subprime financial products that originated in the US housing market (Diamond and Rajan, 2009). ${ }^{2}$ Financial integration was thus a key factor in transforming the crisis in the US housing market into a worldwide banking crisis, during which large financial institutions in many countries had to be rescued by taxpayer monies. In several countries, including Ireland and Iceland, the bailouts were so massive as to threaten the entire state of public finances. ${ }^{3}$

The financial crisis has therefore re-invigorated the debate as to whether increasing internationalization in the banking industry is a desirable development that should be fostered by policy measures to reduce the costs of cross-border banking. One important reason as to why the increasing internationalization of the banking sector may increase its exposure to risk is the limited information about foreign loan markets. Empirical evidence shows that "gravity models", in which distance acts as a proxy for information costs or information asymmetries, are able to explain international transactions in financial services at least as well as they can explain goods-trade transactions (Portes, Rey, and Oh, 2001; Portes and Rey, 2005). Evidence consistent with a theory in which geographical distance acts as a proxy for information costs comes from Acharya, Hasan and Sauners (2006). They show, for a sample of Italian banks during the 1990s, that geographic and sectoral diversification increased the risk of banks' lending portfolios. Similarly, Berger et al. (2005) find that large banks operate at a greater distance than smaller banks and monitor these distant loans less intensively, implying a higher exposure to asset risk. ${ }^{4}$

More generally, however, financial integration in the banking sector may have several, and possible conflicting, effects on the equilibrium level of risk-taking in banks. For example, if economic integration reduces the costs of accessing foreign markets, but information costs remain unchanged and are higher for foreign as compared to domestic

\footnotetext{
${ }^{2}$ Econometric evidence for a sample of large banks across the world confirms that, during this period, the exposure to the US real estate market was a factor that significantly contributed to stock market losses (Beltratti and Stulz, 2012).

${ }^{3}$ The government of Iceland decided to guarantee deposits of domestic investors, but declined to guarantee the deposits of foreigners. Ireland, in contrast, bailed out both domestic and international creditors with taxpayer money. In the fiscal year 2010 alone, this caused an Irish budget deficit equal to $32 \%$ of the country's GDP.

${ }^{4}$ This evidence is not undisputed, however. Goetz, Laeven and Levine (2016) have recently found the opposite result, showing for a US sample of bank holding companies that geographic expansion reduced banks' risks.
} 
customers, then the aggregate level of risk-taking in banks may well increase as a result of falling international transaction costs. Alternatively, if financial integration reduces information costs for banks of supplying foreign customers with credit, then integration is much more likely to reduce the risks that banks incur with their equilibrium loan portfolio.

Against this background, the present paper aims to study the welfare effects of financial integration in a setting that incorporates several characteristics of the banking sector. We set up a model of international trade in services where two banks, one located in each country, engage in cross-border lending to small, competitive firms and make monitoring decisions that determine the riskiness of their operations in their domestic and foreign markets. International lending is subject to two frictions that are not present when banks lend domestically. Firstly, foreign loans are subject to a transaction cost that arises, for example, from foreign loans being denominated in a different currency, or the need to employ the services of a foreign-based intermediary. This will make foreign lending more costly and hence less profitable than lending to domestic firms. Secondly, information costs are higher for lending in the foreign country than in the domestic one due, for example, to diverging national laws and regulations. We shall show that these information asymmetries result in banks monitoring foreign firms less well, resulting in more risky lending in foreign markets.

Another feature of financial markets is that they are heavily regulated. Our model incorporates the fact that the riskiness of bank operations also affects taxpayers, as exemplified by the cases of Ireland and Iceland mentioned above. In our model these spillovers arise not from discrete bail-out decisions, but from government guarantees for the savings deposits that banks use to finance their loans. Such deposit insurance schemes exist in virtually all developed countries, exposing taxpayers to the risks of national bank failures and creating a fundamental moral hazard problem for banks.

We consequently model active governments, setting an optimal capital adequacy standard that forces a bank to hold a minimum amount of equity for each loan it provides. This capital regulation reduces the bank's moral hazard and limits its total loan volume. In setting the optimal capital adequacy standard, the government balances the impact of its regulation policy on the bank's aggregate profits in the domestic and foreign markets, the expected costs to taxpayers that arise in the case of bank failure, and the real effects that the availability of credit has for expected output and hence 
consumer surplus.

While binding capital regulation fixes the total volume of lending, each bank is left to determine the share of its lending to firms in its home market and those in the foreign market. Moreover, banks choose the level of monitoring, and hence the riskiness of their loans, in each market. In the presence of implicit subsidies to risk-taking resulting from the government guarantees, banks will choose too little monitoring and their lending choice will be distorted towards the more risky activity in the foreign market.

In this setting, the focus of our analysis is on the effects that financial integration will have on banks, consumers and taxpayers in each country. We show that these effects differ critically depending on which international friction is reduced.

If economic and financial integration lowers the transaction costs for cross-border lending, while information costs remain unchanged, then the effects of closer integration are predominantly negative. Overall lending and aggregate output would fall in equilibrium, as a result of each bank redirecting more of any given total loan volume towards its foreign market, where its costs are higher. At the same time, the average riskiness of bank lending and hence the expected losses to taxpayers increase, as each bank makes relatively more loans in its foreign market where information is more costly and monitoring levels are therefore lower.

In contrast, if the information costs in the foreign market fall as a result of financial integration, then the effects of such a policy are most likely positive. A shift towards greater lending in the foreign market is now accompanied by increased monitoring, raising expected consumer surplus while reducing the risks to taxpayers. The conclusion from our analysis is, therefore, that it is crucial for financial integration to be accompanied by policies that increase market transparency and reduce information costs, through such instruments as common banking standards and a coordination of national laws pertaining to the enforcement of defaulting loans.

\subsection{Related literature}

Our paper combines elements from across the economics literature. With respect to international trade theory, there is a small strand of literature that explicitly examines the banking sector. Following the early work by Eaton (1994), Lehner and Schnitzer (2008) analyze the spillover effects of FDI in the banking sector on the host country's 
banking system. In contrast, Niepmann (2015) and de Blas and Russ (2013) analyze banks' choices between foreign direct investment and cross-border lending. These papers do not incorporate any policy instruments, however. ${ }^{5}$ On the other hand, a sizeable literature has studied the effects of economic integration on policy competition in trade models with imperfect competition (e.g., Kind, Midelfart and Schjelderup, 2005; Ottaviano and van Ypersele, 2005; Haufler and Wooton, 2010), but these have not been applied to the specific policy issues facing the banking sector.

We also draw on the literature on capital regulation. Several authors have stressed that, in a closed economy, capital regulation increases the risk buffer of banks and curbs risky behaviour (Rochet, 1992; Hellman, Murdock and Stiglitz, 2000). De Nicolò, Gamba and Lucchetta (2012) study optimal capital regulation in a dynamic model of banking in a closed economy. The literature on regulatory competition in the banking sector stresses the result that nationally set capital standards are inefficiently low from a global welfare perspective (Sinn, 1997; Acharya, 2003). The present paper is closest to Dell'Ariccia and Marquez (2006), where regulators choose nationally optimal capital requirements by trading off the aggregate level of banks' profits against the benefits of financial stability. We extend their model and link it to the trade literature, incorporating different types of trade frictions. This allows us to study the effects of financial integration on different agents in the economy, and on national welfare.

A final related literature strand studies issues of risk-taking in connection with the internationalization strategies of banks. The theoretical contributions in this literature are typically based on portfolio-choice models, however, and the microeconomic contributions are primarily empirical (e.g., Beltratti and Stulz, 2012; Buch, Koch, and Koetter, 2013; Ongena, Popov and Udell, 2013).

The remainder of this paper is set up as follows. Section 2 introduces our trade model with goods production and cross-border lending by banks. Section 3 studies the optimal capital regulation by the government. Section 4 analyzes the effects of financial integration, focusing on reductions in trade costs on the one hand and reductions in information costs on the other. Section 5 studies, by means of numerical simulations, how the different types of financial integration feed back on governments' optimal regulation policy. Section 6 concludes.

\footnotetext{
${ }^{5}$ The general literature on trade in services and public policy is surveyed in Francois and Hoekman (2010).
} 


\section{The model}

We consider a region composed of two countries $i$ and $j$. In each country, goods are manufactured by competitive firms that have to borrow in order to be able to produce the output of non-tradeable goods. Each country is the host to a single bank, which can lend to producers in either country. In this respect the model is closely related to the "reciprocal dumping" model of international trade in identical products, originally developed by Brander and Krugman (1983). In the absence of international lending, each bank would be a monopolist in its domestic market. The opportunity to trade in lending results in each bank seeking to acquire a share in its foreign market. This is done by offering loans that are fundamentally identical to those offered by the domestic incumbent but, due to the greater distance between bank and borrower, are more expensive to provide.

Our model departs from that of Brander and Krugman in several further respects. Firstly, the notion of "distance" in our model is not confined to the ("iceberg") trade costs of Brander and Krugman (1983). Such trade costs do exist in our model, and they can be interpreted as the additional transaction costs of supplying a loan to foreign customers. In addition, however, we also consider higher information costs faced by a bank that arise from it being less familiar with the legal framework and potential borrowers in a foreign country. As a consequence, banks may choose to exert different levels of effort in monitoring their domestic and foreign loans.

Secondly, each bank's activities are regulated by its national government. Regulators of the banks set equity requirements that can limit the aggregate quantity of loans that banks are able to offer to firms. Consequently, when this restriction is binding on a bank, it faces a choice as to where to lend its limited funds. The absence of a binding restriction would permit a bank to "segment" its markets, setting lending in each country independently of conditions in the other market. If, however, overall lending is constrained, the bank has to decide upon its lending to the two countries simultaneously. Finally, banks face a fundamental moral hazard incentive in our model, arising from their limited liability. In the event of failure, bank owners are affected only to the extent that the bank's operations are financed by equity, while the losses accruing to depositors are covered by deposit insurance schemes and eventually have to be met by taxpayers. This distorts the banks' choices towards lending in their more risky, foreign markets. 
The timing in our model is as follows. In the first stage, each of the two governments simultaneously sets the equity requirement for its bank. In the second stage, the banks decide upon their lending to each market. When the total funds available to lend exceed a bank's desired lending, then the bank treats each market separately. If, in contrast, the equity requirement is binding, then the bank decides upon the shares of the funds to lend to firms in its domestic and foreign markets. In the third stage, the banks choose the level of monitoring of loans in each of their markets. Finally, in the fourth stage, firms produce output that is sold and consumed domestically. We solve the model using backwards induction.

\subsection{Goods production}

Homogeneous goods are produced in each country by small, competitive firms. There are no fixed costs to production, but each firm requires a bank loan to finance its output activity. Every firm plans to produce one unit of output using a single unit of an input. This input is the numeraire, such that a firm has to borrow a single unit of currency in order to acquire its services. Firms have the choice of whether to borrow from the local bank or the foreign bank. Each firm in country $i$ with a loan from a bank based in country $h \in\{i, j\}$ succeeds in production with probability $q_{i h}$. This probability of success is a positive function of the level of monitoring offered by the lender. A profitmaximising, small firm will be indifferent between the two lenders when its expected profits are the same regardless of the source of funds.

Expected output, $Q_{i}$, in country $i$ is

$$
Q_{i}=q_{i i} L_{i i}+q_{i j} L_{i j}
$$

where $L_{i h}$ is the number of loans made by bank $h$ in country $i$. The good is produced exclusively for domestic consumption. The market inverse demand curve for the good is linear, with the expected price, $P_{i}$, being

$$
P_{i}=A-b_{i} Q_{i}
$$

Substituting (1) into (2) yields the expected price as a function of the expected success of the loans in the market,

$$
P_{i}=A-b_{i}\left(q_{i i} L_{i i}+q_{i j} L_{i j}\right) .
$$


Expected profit for a firm in country $i$ borrowing from bank $h$ at cost $R_{i h}$ is

$$
\pi_{i h}=q_{i h}\left(P_{i}-R_{i h}\right)+\left(1-q_{i h}\right) 0 \quad \forall h \in\{i . j\} .
$$

Firms that fail earn nothing and default on their loans while each successful firm will sell its (unit of) output at the prevailing price. We assume that there is free entry into the goods sector and consequently zero expected profits. This means, from (4), that the cost of a loan from either bank must equal the expected price of the product: ${ }^{6}$

$$
R_{i}=R_{i h}=P_{i} \quad \forall h \in\{i, j\} .
$$

For the remainder of the paper we shall use $R_{i}$ to represent the price in country $i$. Demand for loans can be seen as the derived demand for the consumption good that is produced by firms using these bank loans. Thus the expected price of loans made by banks in country $i$ is

$$
R_{i}=A-b_{i}\left(q_{i i} L_{i i}+q_{i j} L_{i j}\right)
$$

\subsection{Banks}

There are two banks, one based in each country. Each bank can lend in both markets, but faces higher costs in its foreign market where, for example, it may have to engage the services of a local financial intermediary. There is no opportunity for firms to arbitrage loans internationally. If the banks' ability to lend were unlimited, the markets would be segmented, in that lending decisions could be made separately for each market. However, the leading case in our analysis is characterized by the total lending volume of each bank being restricted by capital regulation. Consequently each bank must determine the volume of its loans to each market, subject to the total amount of loans that it is able to make. We denote the total amount of loans made by the bank based in country $i$ by $L_{i}$. The share of bank $i$ 's lending to its domestic market is $\gamma_{i}$, whereas the share $\left(1-\gamma_{i}\right)$ goes to firms in country $j$. The allocation of loans between the two

\footnotetext{
${ }^{6}$ Eq. (5) implies that a firm is indifferent between two equally priced loans in our model, regardless of the levels of monitoring associated with the loans. This is because the firms have zero expected profits. If a firm is successful with production, it repays the loan with the revenue from selling its output. If a firm fails, it defaults on its loan. In either circumstance, the firm breaks even. Thus monitoring of a loan only affects the expected profits of the lending institution, not the firm.
} 
markets can then be written as

$$
\begin{array}{ll}
L_{i i}=\gamma_{i} L_{i}, & L_{i j}=\left(1-\gamma_{j}\right) L_{j}, \\
L_{j i}=\left(1-\gamma_{i}\right) L_{i}, & L_{j j}=\gamma_{j} L_{j} .
\end{array}
$$

Banks' funds come from two sources: a combination of savings deposits and equity. We assume that all of bank $i$ 's deposit finance comes from residents of country $i$. In line with actual practice in virtually all OECD countries, we further assume that savings deposits in country $i$ are insured against bank failures by the government, and hence eventually the taxpayers, of country $i .^{7}$ Therefore depositors do not face any risk and we assume that they supply their savings to the bank for a fixed return, normalized to unity. On the other hand, the equity holders in bank $i$ partly reside in country $i$, but may also be residents of a third country outside the union. ${ }^{8}$ This is consistent with a setting where countries $i$ and $j$ are small in the world capital market, but investors in each country exhibit a home bias for their national bank. We denote the total equity of bank $i$ by $E_{i}$ and assume, for analytical simplicity, that each bank's cost of equity is also unity. ${ }^{9}$

The banking regulator in country $i$ imposes a capital-adequacy standard, $k_{i}$, that represents the minimum proportion of bank lending that is backed by the bank's equity, as opposed to consumer deposits. The total lending of a bank, $L_{i}$, may then be limited by the quantity of equity that it owns:

$$
L_{i} \leq \frac{E_{i}}{k_{i}}
$$

We shall investigate the implications of (8) being a binding constraint on the bank's lending activities, where it has to balance the benefits of lending in one market relative to the other.

\footnotetext{
${ }^{7}$ The main argument for deposit insurance is that it prevents bank runs and thereby stabilizes the banking system (Diamond and Dybvig, 1983). See Barth, Lee and Phumiwasana (2006) for an overview of deposit insurance schemes around the world, and for a discussion of its benefits and costs.

${ }^{8}$ In other words, bank $i$ 's profit may accrue only partially to domestic residents. As we will see below, cross-ownership of country $j$ 's residents in bank $i$ has the same implications as domestic ownership in our analysis, since we focus on symmetric equilibria and do not consider policy competition between countries $i$ and $j$.

${ }^{9}$ The usual assumption in the literature is that the cost of equity is fixed at a level equal to or higher than the cost of savings deposits (Dell' Ariccia and Marquez, 2006; Allen, Carletti and Marquez, 2011). In such a setting, higher capital requirements increase the bank's cost of equity for two reasons, the higher cost of equity and the reduced subsidization by taxpayers. We simplify the analysis by eliminating the first of these effects but, importantly, maintain the second.
} 
With these specifications, the costs of finance for bank $i$ in its local and foreign markets are, respectively,

$$
\begin{aligned}
& C_{i i}=1-\left(1-q_{i i}\right)\left(1-k_{i}\right), \\
& C_{j i}=(1+\tau)-\left(1-q_{j i}\right)\left(1-k_{i}\right) .
\end{aligned}
$$

In the expression for $C_{j i}$, the term $\tau$ reflects the additional transaction cost of servicing a loan in the bank's foreign market. One example of such costs are the fees charged by foreign financial intermediaries which are often involved in loan contracts with foreign firms, in order to reduce the risk of a loan default. Another example are the extra transaction costs of hedging the exchange rate risk associated with a foreign loan.

The second term in each expression in (9) reflects the implicit subsidy from the taxpayer that the bank will receive as a result of deposit insurance. The subsidy equals the product of the probability of default $\left(1-q_{h i}\right)$ and the share of financing through deposits $\left(1-k_{i}\right)$. To keep the analysis tractable, we assume that the risks across the different firms in each country are perfectly correlated so that the probability of failure by firms equals the probability that bank $i$ will also fail. ${ }^{10}$ Hence, the (expected) costs of bank failures are partly borne by the taxpayers of the bank's country of residence. ${ }^{11}$ An increase in the capital requirement $k_{i}$ reduces this implicit subsidy to the bank and thus raises its cost of finance $C_{i}$.

Monitoring decision. We assume that a bank can affect the probability that a firm succeeds through the level of monitoring, or support, that the bank provides. ${ }^{12}$ The greater the monitoring, the greater the likelihood that the good will be produced and sold, and the higher the probability that the loan will be repaid. Suppose that the likelihood of a firm's success is linear in monitoring such that (with the appropriate normalisation) $q_{h i}$ of monitoring by bank $i$ to a firm in country $h$ yields a probability

\footnotetext{
${ }^{10}$ See Dell'Ariccia and Marquez (2006) for a similar assumption.

${ }^{11}$ Our analysis abstracts from insurance funds paid by the banking sector. From 2016 onwards the member states of the European Union, for example, are building up an EU-wide 'resolution fund', financed by levies on member states' banks. This fund, however, is built up only gradually and with a moderate overall target volume.

${ }^{12}$ One possible interpretation is that by monitoring the producing entrepreneur, the bank induces him to supply more effort, thus increasing the probability of success (Besanko and Kanatas, 1993). Alternatively, monitoring can also be interpreted as the bank acquiring a knowledge that is complementary to that of the firm, helping the firm to raise its chance of success (Boot and Thakor, 2000).
} 
of industrial success equal to $q_{h i}$. Thus monitoring of $q_{h i}$ results in the bank's expected earnings on the loan equalling $R_{h} q_{h i}$.

While monitoring raises the expected return on a loan, it is costly to provide. We assume that monitoring costs are quadratic in the amount of monitoring and that they are sufficiently large that there will never be perfect monitoring in equilibrium. For domestic loans, the monitoring costs are thus given by $s q_{i i}^{2} / 2$, where $s(>0)$ is a constant. Foreign loans face higher monitoring costs as a result of higher information costs for foreign customers. ${ }^{13}$ In general, information costs are higher for banks when lending in foreign markets because of the different institutional and legal setting in which the foreign customer operates. These differences are particularly important when it comes to (partially) recovering the loan in the case of a borrower default. The European Commission (2015, p. 23), for example, stresses in its action plan for a capital markets union in Europe, that differences in insolvency, collateral and securities laws represent important barriers for cross-border lending. ${ }^{14}$ In our model these costs are specified as $s(1+\sigma) q_{j i}^{2} / 2$, where $\sigma(>0)$ parameterizes the extra information costs of foreign loans.

Each bank makes an individual decision as to how much monitoring it should conduct on each loan. As firms are assumed to be identical, a bank will optimally choose the same level of monitoring for all firms in a particular (domestic or foreign) market. The banks will take the price of the loan $R_{i}$ [which equals the expected price of output from (5)] as given when making their monitoring decision. The reason why firms cannot strategically exploit their market power through their monitoring decision is that the risks of firms in each country are perfectly correlated (see above). While lowering $q_{h i}$ would increase the probability that all firms fail, it will not increase the market price that firms receive when they - simultaneously - succeed. Hence firms will not increase their willingness to pay for a bank loan when the bank's monitoring level falls.

The expected operating profit of bank $i$ is $\Pi_{i}$, which is the sum of its net expected earnings in its home and foreign markets. Using (7), this can be written as

$$
\Pi_{i}=\alpha_{i i} L_{i i}+\alpha_{j i} L_{j i}
$$

\footnotetext{
${ }^{13}$ See Portes, Rey and Oh (2001) for empirical evidence that information costs are rising in the distance between borrowers and lenders.

${ }^{14}$ See also Degryse et al.(2016) for a recent empirical study of how institutional and legal differences across countries affect banks' recovery rates on collateral. This study incorporates detailed data of firms' underlying assets pledged as collateral for a bank loan.
} 
where $\alpha_{i i}$ and $\alpha_{j i}$ are bank $i$ 's expected returns on domestic and foreign loans, respectively:

$$
\alpha_{i i} \equiv R_{i} q_{i i}-C_{i i}-\frac{s}{2} q_{i i}^{2} ; \quad \alpha_{j i} \equiv R_{j} q_{j i}-C_{j i}-\frac{s(1+\sigma)}{2} q_{j i}^{2} .
$$

In (11), the costs of finance are as given in (9), whereas the last term in each expression represents the monitoring costs for domestic and foreign loans, respectively.

Substituting (11) into (10) and differentiating with respect to levels of monitoring (treating expected price as a constant), yields first-order conditions for the profitmaximising levels of monitoring in both markets:

$$
q_{i i}^{*}=\frac{R_{i}-\left(1-k_{i}\right)}{s} ; \quad q_{j i}^{*}=\frac{R_{j}-\left(1-k_{i}\right)}{s(1+\sigma)} .
$$

A bank's monitoring of firms in a market is positively related both to the price and to the capital constraint facing the bank. High prices make successful performance more rewarding while a higher capital constraint, by reducing the share of subsidized deposit financing, increases the cost of failure from the bank's perspective. Finally, and importantly, the probability of a failing loan is always greater for the foreign operations of a bank, because of the higher information costs associated with foreign lending. ${ }^{15}$

The monitoring levels in (12) can be substituted into (11) to find the expected earnings on optimally monitored loans in each market:

$$
\alpha_{i i}^{*}=\frac{\left[R_{i}-\left(1-k_{i}\right)\right]^{2}}{2 s}-k_{i} ; \quad \alpha_{j i}^{*}=\frac{\left[R_{j}-\left(1-k_{i}\right)\right]^{2}}{2 s(1+\sigma)}-\left(k_{i}+\tau\right) .
$$

Loan allocation. The optimal allocation of lending between bank $i$ 's markets is found by partially differentiating (10) with respect to $\gamma_{i}$, taking into account (6) and (7). This gives the first-order condition

$$
\frac{\partial \Pi_{i}}{\partial \gamma_{i}}=\alpha_{i i}^{*}-\alpha_{j i}^{*}-\left[\gamma_{i} b_{i} q_{i i}^{* 2}-\left(1-\gamma_{i}\right) b_{j} q_{j i}^{* 2}\right] L_{i}=0
$$

Solving and rearranging yields the optimal allocation of lending

$$
\gamma_{i}^{*}=\frac{s(1+\sigma)\left[(1+\sigma) \phi_{i i}^{2}-\phi_{j i}^{2}+2 s(1+\sigma) \tau\right]+2 L_{i} b_{j} \phi_{j i}^{2}}{2 L_{i}\left[(1+\sigma)^{2} b_{i} \phi_{i i}^{2}+b_{j} \phi_{j i}^{2}\right]},
$$

\footnotetext{
${ }^{15}$ In a setting where the risks are perfectly correlated between the firms in each country, such a difference between the risks involved for domestic and foreign banks can be interpreted, for example, by each bank being more familiar with its domestic legal system, and therefore being better able to monitor or support domestic firms in the face of macroeconomic shocks.
} 
where $\phi_{h i}$ is bank $i$ 's return on a successful loan in market $h$, net of the cost of deposit finance:

$$
\phi_{i i} \equiv R_{i}-\left(1-k_{i}\right), \quad \phi_{j i} \equiv R_{j}-\left(1-k_{i}\right)
$$

Symmetry. Suppose now that the two countries are identical to each other, such that they have the same population size $b=b_{i}=b_{j}$, and have identical prices (for goods and loans) $R=R_{i}=R_{j}$. This implies $\phi_{j i}=\phi_{i i} \equiv \phi_{i}$ in (16). We also assume that the banks behave optimally with respect to their monitoring and lending decisions such that we can suppress the asterisk $\left(^{*}\right)$ from here on.

We can use the symmetry to determine the values of the exogenous parameters in our model that will ensure that the banks' optimal monitoring decisions yield interior solutions. For both $q_{i i}<1$ and $q_{j i}<1$ to hold in (12) we need that $\phi_{i}<s$. At the same time, to ensure that expected earnings in both markets are positive, $\alpha_{i i}>0$ and $\alpha_{j i}>0$, in (13) requires that $\phi_{i}^{2}>2 s(1+\sigma)\left(k_{i}+\tau\right)$. These conditions can be simultaneously fulfilled only if

$$
s>\phi_{i}>2(1+\sigma)\left(k_{i}+\tau\right) .
$$

Condition (17) thus places an upper bound on the additional monitoring cost in the foreign market, $\sigma$, relative to both the domestic monitoring cost parameter $s$, and the bank's return on a successful loan $\phi_{i}$. We will use this condition in our analysis below. We can further exploit the symmetry in order to simplify our expression [eq. (15)] for the optimal share of lending allocated to the home market:

$$
\gamma_{i}=\frac{1}{b L_{i}\left[(1+\sigma)^{2}+1\right]}\left[b L_{i}+\frac{s(1+\sigma) \sigma}{2}+\frac{s^{2}(1+\sigma)^{2} \tau}{\left[R-\left(1-k_{i}\right)\right]^{2}}\right] .
$$

If the banks do not face any additional costs for operating in the foreign market, then both $\tau=0$ and $\sigma=0$. Consequently, (18) further simplifies to $\gamma_{i}=1 / 2$ (see Dell'Ariccia and Marquez, 2006).

More generally, however, the share of domestic bank loans, $\gamma_{i}$, can be greater or less than $1 / 2$. To see this, we focus on the role of the cross-border information cost $\sigma$ and set $\tau=0$ in (18). Subtracting $1 / 2$ from both sides gives

$$
\left.\gamma_{i}\right|_{\tau=0}-\frac{1}{2}=\frac{\sigma\left[s(1+\sigma)-b\left(E_{i} / k_{i}\right)(2+\sigma)\right]}{2 b\left(E_{i} / k_{i}\right)\left[(1+\sigma)^{2}+1\right]} \gtrless 0,
$$


where we have substituted (8) for $L_{i}$ to highlight the dependence of the inequality on the capital requirement $k_{i}$.

Equation (19) shows an important property of our model. Even though they face higher information costs for foreign loans, banks may provide more loans in their foreign markets than in their domestic markets. This is because banks are effectively subsidized by taxpayers through the deposit insurance scheme. Since this subsidy is proportional to the risk of failure, the foreign loans of each bank receive a disproportionate subsidy compared to their domestic loans. This leads to the (expected) marginal costs of finance being lower for foreign loans compared to domestic loans, if the trade cost parameter $\tau$ is low [see eq. (9) taking into account that $q_{i i}>q_{j i}$ from (12)]. Hence, banks will enter foreign markets "aggressively" when the costs of failure are shared with taxpayers at home.

Specifically, when $\tau$ is low, $\gamma_{i}>1 / 2$ will result in our model only when the information cost parameter $s$ (which acts as a multiplier for the foreign information costs $\sigma$ ) is large and when the subsidy share implicit in deposit insurance is low ( $k_{i}$ is large). In the opposite case, where $s$ and $k_{i}$ are both small, the higher subsidization of foreign loans is the dominant effect and $\gamma_{i}<1 / 2$ holds in equilibrium.

\section{Government regulation}

The banking regulator of the government in country $i$ can intervene in the financial market through setting $k_{i}$, the equity requirement for bank $i$ 's lending. As a benchmark, we first consider the case where no capital requirements are set by national regulators and hence the constraint (8) does not bind. We then look at the implications of increases in $k_{i}$ that are sufficiently large to affect the bank's lending decisions in both markets.

\subsection{Non-binding capital regulation}

When the total loan volume that can be made by a bank exceeds its desired volume of lending $\left(L_{i}<E_{i} / k_{i}\right)$, government equity requirements do not limit the activities of the bank. In this setting the banks make independent decisions regarding their lending in their domestic and foreign markets. Thus, rather than making a decision regarding the allocation of limited lending between the two markets to maximize (14), bank $i$ is free 
to choose its lending in each market to maximize each of $\Pi_{i i} \equiv \alpha_{i i} L_{i i}$ and $\Pi_{j i} \equiv \alpha_{j i} L_{j i}$. The financial products provided by the two banks to firms in a particular market will not be the same, in that the level of monitoring of loans by the domestic bank will differ from that chosen by its foreign rival.

Total lending in market $i$ will result from each bank choosing its optimal number of loans, given its rival's lending decision. ${ }^{16}$ Differentiating the bank's profits in each market, we can solve the first-order conditions to obtain the optimal loan volumes:

$$
L_{i i}=\frac{\alpha_{i i}}{b_{i} q_{i i}^{2}}, \quad L_{i j}=\frac{\alpha_{i j}}{b_{i} q_{i j}^{2}}
$$

Taking into account the inverse demand function (3) that links the lending levels of the two banks, we can derive the reaction functions for lending by the domestic and foreign banks in the market:

$$
\begin{aligned}
& L_{i i}\left(L_{i j}\right)=\frac{1}{2 b_{i}}\left[\frac{A-\left(1-k_{i}\right)}{q_{i i}}-\frac{s}{2}-\frac{k_{i}}{q_{i i}^{2}}\right]-\frac{q_{i j}}{q_{i i}} \frac{L_{i j}}{2} ; \\
& L_{i j}\left(L_{i i}\right)=\frac{1}{2 b_{i}}\left[\frac{A-\left(1-k_{j}\right)}{q_{i j}}-\frac{(1+\sigma) s}{2}-\frac{k_{j}+\tau}{q_{i j}^{2}}\right]-\frac{q_{i i}}{q_{i j}} \frac{L_{i i}}{2} .
\end{aligned}
$$

It is immediately apparent from (21) that one bank's lending is a strategic substitute for loans from the other bank. Further, we can see that, for any level of funds being provided by the domestic bank, the foreign bank's lending is affected negatively by both the trade cost $\tau$ that it faces, as well as the additional information cost of lending abroad $\sigma$.

The slopes of the two reaction functions depend upon the levels of monitoring established by the domestic and foreign banks, $q_{i i}$ and $q_{i j}$, respectively. If these were the same, both reaction functions would have a slope of (negative) $1 / 2$. To get a clearer idea of the Cournot-Nash equilibrium that would occur in lending in this market, assume that the capital requirements are the same for both banks $\left(k=k_{i}=k_{j}\right)$ and return to our assumption that demand for goods in the two countries is the same $\left(b=b_{i}=b_{j}\right)$. Substituting this into (12) yields $q_{i j}=q_{i i} /(1+\sigma)$, showing that foreign loans are less well-monitored than those made by a local lender. We can then use (21)

\footnotetext{
${ }^{16}$ We assume that each bank behaves as a Cournot competitor in that, in making its decision as to the quantity of loans that it will offer in a market, it assumes that its competitor's response will be to maintain its level of lending.
} 
to find each bank's optimal allocation of loans to its domestic and foreign markets, $L_{i i}$ and $L_{i j}$ respectively. Solving yields:

$$
\begin{aligned}
& L_{i i}=\frac{1}{3 b}\left\{\left[\frac{A-(1-k)}{q_{i i}}-\frac{s}{2}\right]-\frac{[(1+\sigma) \tau-(1-\sigma) k]}{q_{i i}^{2}}\right\} ; \\
& L_{i j}=\frac{(1+\sigma)}{3 b}\left\{\left[\frac{A-(1-k)}{q_{i i}}-\frac{s}{2}\right]-\frac{[2(1+\sigma) \tau+(1+2 \sigma) k]}{q_{i i}^{2}}\right\} .
\end{aligned}
$$

We see from (22) that the trade cost $\tau$ reduces lending in both markets but that this effect is stronger in the bank's foreign market. The role of the additional information cost facing the foreign lender $\sigma$ is less clear. If this cost is sufficiently large, the second term in the expression for $L_{i j}$ will outweigh the first term, such that there is no foreign lending. However, when $\tau$ and $k$ are both small (so that the second terms in the braces are negligible) while $\sigma$ is positive, this will lead to the foreign bank lending more in the market than its domestic rival. In the face of higher information costs, the foreign bank will provide an inferior (that is, less well-monitored) product than that offered by the local bank and this may crowd out the superior local product. As discussed above [eq. (19)], this is due to implicit government subsidies that are proportional to the banks' risk-taking and thereby favour the foreign- over the domestic-lending operations of each bank.

Finally, we can add together the two expressions in (22) to obtain the total amount of lending when the capital requirement $k$ increases the bank's lending costs but does not impose an overall constraint on the bank's lending volume. Denoting this unconstrained level of aggregate lending by $L_{i}^{u}$ we find

$$
L_{i}^{u}=L_{i i}+L_{j i}=\frac{(2+\sigma)}{3 b}\left[\frac{A-(1-k)}{q_{i i}}-\frac{s}{2}\right]-\frac{\left[(1+\sigma)(1+2 \sigma) \tau+2\left(1+\sigma+\sigma^{2}\right) k\right]}{3 b q_{i i}^{2}} .
$$

In the following we shall compare $L_{i}^{u}$ to the level of lending in the constrained regime.

\subsection{Binding capital regulation}

We now consider how the allocation of lending changes when a bank's total lending $L_{i}$ is constrained by its equity holdings and the equity requirement (8) imposed by the regulator. In this paper we analyze the effects of coordinated changes in the two countries' capital requirements. In other words, we assume that the two, symmetric countries 
jointly set their capital requirements so as to maximize their combined welfare. This assumption reflects the fact that, at least in the developed world, bank regulation has been closely coordinated through the various Basel agreements. ${ }^{17}$ Also, since our focus is on the effects of economic and financial integration, rather than on regulatory competition between governments, our assumption of a coordinated regulatory regime is an analytically simpler way to pin down optimal levels of $k_{i}{ }^{18}$ Consequently, we continue our analysis under the assumption that there is a common capital requirement $k=\left(k_{i}=k_{j}\right)$ across the region.

We first discuss the conditions under which the lending constraint actually has an impact on the equilibrium. Comparing the unconstrained level of lending in (23) with the constrained level $L_{i}=E_{i} / k$ shows that $L_{i}^{u}<L_{i}$ must hold as $k \rightarrow 0$. This is because the available lending $L_{i}$ approaches infinity as $k$ approaches zero, whereas $L_{i}^{u}$ converges towards a finite value. Hence the economy can only be in the constrained regime when $k$ is significantly above zero. Evaluating expressions at the maximum capital ratio of unity (which implies full equity financing of the bank's loans), a necessary condition for the constrained regime to occur at some levels of $k$ is then:

$$
\left.L_{i}\right|_{k=1}=E_{i}<\left.L_{i}^{u}\right|_{k=1} .
$$

Clearly, condition (24) must hold when the bank's equity $E_{i}$ is sufficiently low, relative to the exogenous parameters that determine $L_{i}^{u}$ in (23). We make this assumption in the following.

We assume that governments set capital requirements to maximize a welfare function that is a weighted sum of the expected profits of the domestic bank $\left(\Pi_{i}\right)$, tax revenues $\left(T_{i}\right)$, and consumer surplus in the domestic goods market $\left(C S_{i}\right)$. Hence the welfare function of each government is

$$
W_{i}=\beta_{1} \Pi_{i}+\beta_{2} T_{i}+\beta_{3} C S_{i}, \quad \beta_{1}, \beta_{2}, \beta_{3} \geq 0 .
$$

\footnotetext{
${ }^{17}$ The recent Basel III agreement, enacted in 2013, has increased the ratio of core capital (common equity) to risk-weighted assets from $3.5 \%$ to $4.5 \%$. In addition, an anticyclical capital buffer of $2.5 \%$ of risk-weighted assets is to be built up until 2019.

${ }^{18}$ In the literature on regulatory competition, Sinn (1997) and Dell'Ariccia and Marquez (2006) have shown that the non-cooperative setting of capital standards leads to a "race to the bottom" when each government is mainly interested in the profits of its banking sector. Haufler and Maier (2016) have recently demonstrated, however, that this result may be turned around, and a "race to the top" in capital regulation occurs when governments give equal weighting to banks' profits, tax revenues and consumer surplus.
} 
This welfare function allows for several specifications, depending upon the weights $\beta_{1}$, $\beta_{2}$, and $\beta_{3}$ on profits, tax revenues, and consumer surplus, respectively. For example, if the bank's profits accrue partly to foreigners from outside the region (cf. footnote 8), then $\beta_{1}$ would be set lower than $\beta_{2}$ and $\beta_{3}$. Moreover, the expected subsidies paid to banks may have to be financed by increases in distortive taxes, creating an excess burden over and above the direct fiscal cost of the subsidy. This would imply setting $\beta_{2}$ above both $\beta_{1}$ and $\beta_{3}$. Obviously, when expected fiscal losses are so large that they threaten the entire state of public finances (as happened to Ireland in 2010; see footnote 3), then the welfare weight on tax revenues would have to be even higher.

The first component of (25), bank profits in country $i$, is given in (10). The expected value of tax losses in country $i$ equals the expected value of the loans made by its domestic bank going bad in both countries, when these have been backed by insured deposits as opposed to being funded from the domestic bank's own equity. Tax revenue $T_{i}$ is therefore negative and given by:

$$
T_{i}=-(1-k) B_{i} L_{i}
$$

where $B_{i}$ is the weighted average of failing loans in the home and foreign countries:

$$
B_{i} \equiv\left(1-q_{i i}\right) \gamma_{i}+\left(1-q_{j i}\right)\left(1-\gamma_{i}\right)
$$

Finally, consumer surplus in country $i$ depends on the number of successful loans extended by both banks to firms in country $i$ :

$$
C S_{i}=\frac{b}{2}\left[q_{i i} \gamma_{i} L_{i}+q_{i j}\left(1-\gamma_{j}\right) L_{j}\right]^{2}
$$

In the following, we first derive the effects of coordinated changes in capital requirements on each bank's allocation of loans to the two markets and on equilibrium loan prices. In a second step, we use these results to derive the effects of tighter capital requirements on bank profits, tax revenues and consumer surplus. Finally, we discuss the optimal coordinated choice of capital requirements that maximizes joint welfare in the two countries.

In order to reduce further the complexity of the algebra, we evaluate all effects when trade costs are zero $(\tau=0)$. All of the effects that we derive are for the case where countries are completely symmetric. Hence, for the remainder of this paper, we drop the subscript $i$ from variables. It must therefore be borne in mind that our comparativestatic exercises measure the impact on each country. 
Effect on market shares and loan prices. Differentiating (18) with respect to the common capital requirement $k$, evaluating at $\tau=0$ and using symmetry gives

$$
\left.\frac{\partial \gamma}{\partial k}\right|_{\tau=0}=\frac{s \sigma(1+\sigma)}{2 b L\left[(1+\sigma)^{2}+1\right] k}>0
$$

A coordinated rise in $k$ unambiguously raises the share of loans that each bank directs to its domestic market. Intuitively, a rise in $k$ reduces the implicit subsidization of bank loans arising from savings deposit insurance. Since foreign loans are more heavily subsidized due to their lower level of monitoring, reducing the subsidy redirects the loans of a bank from its foreign to its domestic market.

The effects of tighter capital requirements on loan prices are obtained by differentiating (6). The appendix derives

$$
\left.\frac{\partial R}{\partial k}\right|_{\tau=0}=\frac{b L}{\mu}\left[\frac{\phi}{k}\left(1+\frac{\sigma}{\left[(1+\sigma)^{2}+1\right]}\right)-(1+\gamma \sigma)\right]>0,
$$

where $\phi$ is defined in $(16)$ and $\mu \equiv s(1+\sigma)+b L(1+\gamma \sigma)>0$.

Equation (30) can be signed with the help of condition (17), adjusted for $\tau=0$. Intuitively, the reduced lending volume caused by a coordinated increase in capital requirements directly reduces output and increases the commodity and loan price in each country. A counteracting effect arises from the simultaneous shifting of both banks' loans towards their home markets, where the monitoring intensity and hence the probability of success are higher. However, aggregate output, which equals the product of lending volumes and their respective success rates [eq. (1)], must fall when interior levels of monitoring are chosen and condition (17) holds. Hence the price of loans is always driven up when $k$ rises.

Effects on bank profits, taxpayers and consumers. We now turn to the effects of tighter capital requirements on a bank's profits. Substituting the optimized returns on loans in (13) into (10), differentiating with respect to $k$ and using symmetry yields

$$
\frac{\partial \Pi}{\partial k}=\left\{-B-\left[\frac{\phi^{2}(1+\gamma \sigma)}{2 s(1+\sigma) k}-1\right]+\frac{\phi^{2} \sigma}{2 s(1+\sigma)} \frac{\partial \gamma}{\partial k}+\frac{(1+\gamma \sigma) \phi}{s(1+\sigma)} \frac{\partial R}{\partial k}\right\} L<0,
$$

where $B$ is defined in (27).

The first term in (31) is the direct effect of reducing the subsidization of the bank's lending by means of a tougher capital requirement. This term is clearly negative. The 
second term is also unambiguously negative [cf. condition (17)], as an increase in $k$ reduces the aggregate volume of profitable loans. In contrast, the third and fourth effects are positive, as the increase in capital requirements shifts lending to the more profitable home market [eq. (29)] and increases the price of loans from eq. (30). The ambiguity can be resolved, however, because a binding constraint on lending implies that the bank could increase its profits by expanding its aggregate number of loans. Hence, if the constraint is binding, $\partial \Pi / \partial L>0$ must hold. Differentiating $\Pi$ with respect to $L$, holding $k$ (and thus the subsidy rate for failing loans) fixed and noting that $\partial L / \partial k=-L / k$ shows that the negative second effect must dominate the sum of the third and fourth effects. Hence we can unambiguously conclude that the bank's profits fall following a tighter capital requirement, a result of both the direct first effect and the sum of the indirect effects.

Turning to the effects on a country's taxpayers, differentiating (26) with respect to $k$ and using (30) yields:

$$
\frac{\partial T}{\partial k}=\left\{B+\frac{(1-k) B}{k}+\frac{(1-k)(1+\gamma \sigma)}{s(1+\sigma)}+\frac{(1-k) \phi \sigma}{s(1+\sigma)} \frac{\partial \gamma}{\partial k}\right\} L>0
$$

which is unambiguously positive from (26) and (29). The first of the four terms in (32) gives the direct effect of reducing the subsidy rate for failing bank loans. Total taxpayer subsidies fall further due to the reduction in the overall loan volume (the second effect). The third effect arises from the higher monitoring levels, and hence increased success probabilities, that are induced by the more stringent capital requirements [see eq. (12)]. Finally, through the fourth effect, the increase in $k$ shifts a higher share of the remaining loan volume to the bank's home market, where monitoring rates are higher. In sum, the costs to taxpayers resulting from deposit insurance unambiguously decline with higher equity requirements, as less of the financing is subsidized, lending falls in both markets, and the induced increase in the bank's monitoring of its lending portfolio results in fewer bad debts.

In addition to the effects on the bank and taxpayers, the change in the equity requirement will have consequences for the quantities of goods produced in both markets and will therefore have an impact on the country's consumers. Differentiating the national consumer surplus expression in (28) yields:

$$
\frac{\partial C S}{\partial k}=-Q L \frac{\partial R}{\partial k}<0
$$


where $Q>0$ is expected national output [from (1)] and $\partial R / \partial k>0$ [from (30)]. The increased loan rate reflects the fall in aggregate output following tighter capital requirements. Hence consumer surplus must also fall.

Optimal capital regulation. We can now analyze the optimal setting of the coordinated capital requirement $k$ by substituting the effects of higher capital requirements on profits, tax revenues and consumer surplus [derived in equations (31)-(33)] into the welfare function (25). By choosing an optimal, coordinated, capital requirement $k$, the two governments jointly weigh the effects on the three components of national welfare and directly affect the degree of "bail-in" versus "bail-out", that is, the share of losses borne by equity holders and taxpayers, respectively.

In order to analyze the conditions under which an interior optimum for $k$ exists, we first argue that $\partial W / \partial k>0$ holds at a lower bound for $k$, implying that a small increase in $k$ is raises the country's welfare at this point. This natural lower bound is the level of $k$ at which the constraint on a bank's total loan volume, as given in (8), just binds. We denote this level by $\tilde{k}(>0)$. Consequently, when evaluated at $\tilde{k}$, both the unconstrained model analyzed in Section 3.1. and the constrained model of Section 3.2 yield the same allocation. Since lending is effectively unconstrained at $\tilde{k}$, the indirect effects on banks' profits, as given by the second, third and fourth effects in (31), must sum to zero at this point. Moreover the negative first effect in the profit equation (31) is offset by the positive first effect in the revenue equation (32) when the welfare weight on taxpayers is at least as high as that on bank profits (that is, $\beta_{1} \leq \beta_{2}$ ). The remaining condition for welfare to be rising in $k$ at $k=\tilde{k}$ is that the positive indirect effects in the revenue expression (32) dominate the negative effect on consumer surplus in (33). This will be the case when $\beta_{2}$ is sufficiently large relative to $\beta_{3}$.

Consider now the opposite case where banks are required to fund their lending entirely from equity, that is $k=1$. Then none of the bank's lending is insured and taxpayers are exposed to no risk from bad debts. In that case, the second, third and fourth terms in (32) are all zero, while the first term in (32) exactly offsets the first term in (31) whenever $\beta_{1}=\beta_{2}$. Moreover, the sum of the remaining effects on bank profits in (31) is certainly negative at $k=1$, as the banks are constrained in their overall lending volume. Finally, the effect on consumer surplus in (33) is also negative. Under these conditions $\partial W / \partial k<0$ holds unambiguously when evaluated at $k=1$. 
These conditions ensure that $W$ is rising at $k=0$ but falling at $k=1$, implying that $W$ is concave in the policy parameter $k$ in the relevant interval. Moreover, $W$ must be continuous in $k$, because all components of national welfare are continuous in $k$. Hence an interior maximum $0<k<1$ must exist. We summarize the conditions for obtaining such an interior optimum in the following proposition. ${ }^{19}$

Proposition 1 If the welfare weights on bank profits and tax revenues are equal and sufficiently larger than the welfare weight on consumer surplus $\left(\beta_{1}=\beta_{2}>\beta_{3}\right)$, then a joint policy optimum exists in which the two governments choose a coordinated, interior capital requirement with $0<k<1$.

Note that the conditions specified in Proposition 1 are sufficient, but not necessary, for an interior policy equilibrium to exist. It is then straightforward to determine how the optimal capital requirement $k$ responds to the weights $\beta$ attached to the different components of national welfare. From the implicit function theorem, we get

$$
\begin{aligned}
\frac{\partial k}{\partial \beta_{1}} & =-\frac{\partial \Pi / \partial k}{\partial^{2} W / \partial k^{2}}<0, \\
\frac{\partial k}{\partial \beta_{2}} & =-\frac{\partial T / \partial k}{\partial^{2} W / \partial k^{2}}>0, \\
\frac{\partial k}{\partial \beta_{3}} & =-\frac{\partial C S / \partial k}{\partial^{2} W / \partial k^{2}}<0,
\end{aligned}
$$

where the individual effects can be signed from (31)-(33). The comparative static effects of changes in the welfare weights on the optimal level of $k$ are summarized in:

Proposition 2 The optimal capital requirement $k$ is rising in the weight that governments attach to tax revenues $\left(\beta_{2}\right)$ and falling in the weights that they attach to bank profits $\left(\beta_{1}\right)$ and consumer surplus $\left(\beta_{3}\right)$.

Our results in this section are consistent with the empirical finding that worldwide levels of cross-border lending have fallen since 2008 (see Figure 1). During this period,

\footnotetext{
${ }^{19}$ De Nicolò et al. (2012) find a similar result in a dynamic banking model of a closed economy, as bank efficiency and welfare first rise when capital standards are increased, and then fall when capital standards become "too stringent". In their model, however, the trade-off arises from behavioural responses within the banking sector, not from the diverging interests of banks, taxpayers and consumers, as is the case here.
} 
capital requirements have been increased through the coordinated Basel III process (see footnote 17), but also through unilateral measures taken in several countries, including the United States and Switzerland. In the setting of our model, this increase in $k$ can be motivated by a higher valuation of taxpayer costs (i.e., an increase in $\beta_{2}$ ) following the public bailout of banks that has occurred in many countries (Proposition 2). Moreover, our above analysis has shown that higher capital requirements not only reduce the overall volume of lending [eq. (30)], but also shift lending activities towards the domestic market [eq. (29)]. This strongly suggests that the change in regulation policy that occurred after the financial crisis has contributed to lower levels of cross-border lending.

In our analysis of financial integration in the following section, we treat the capital requirement $k$ as exogenous (and common to both countries), but interpret it as having been chosen optimally before any changes in the costs of foreign lending have occurred. In Section 5, we will then analyze, by means of numerical simulations, how the governments' optimal capital requirement is affected by this financial integration.

\section{Financial integration}

Improvements in technology or information can reduce the cost to a bank of lending in a foreign market. This enhances the entry of financial institutions into foreign markets and has implications for the overall level of lending as well as the quality of loans. In our model we have two parameters that capture different elements of financial integration. Firstly, a reduction in the trade cost parameter $\tau$ facilitates access to the foreign market but leaves unchanged the extra costs of monitoring foreign loans. Secondly, improved information on foreign loans are captured by a decrease in the foreign information cost parameter $\sigma$. As we shall show, changes in these two parameters have very different welfare implications in our model.

\subsection{Reduced costs for trade in services}

We start with the analysis of reductions in trade costs $\tau$. One example of reduced trade costs is the use of a common currency in the Euro area, which eliminates the need for hedging exchange rate risks. Another example comes from the current initiative to create a capital markets union among the EU member states. A core element in this 
initiative is the increased use of "simple, transparent and standardized" securitization, which is aimed explicitly at reducing the costs of cross-border lending (see European Commission, 2015a,b).

In parallel to our analysis in the previous section, we start by deriving the effects of this policy change on a bank's allocation of its total lending and on the price of loans. In a second step, we then derive the effects on profits, tax revenues and consumer surplus. In contrast to our analysis in Section 3.2, we analyze the effects of changes in trade costs from an arbitrary initial equilibrium where $\tau$ is strictly positive.

Effect on market shares and prices. Differentiating a bank's allocation of loans in (18) with respect to $\tau$ yields

$$
\frac{\partial \gamma}{\partial \tau}=\frac{s^{2}(1+\sigma)^{2}}{\phi^{2} b L \varepsilon}>0
$$

where $\varepsilon \equiv\left[(1+\sigma)^{2}+1\right][s(1+\sigma)+b L(1+\gamma \sigma)]-\tau s^{2} \sigma(1+\sigma)^{2}>0$.

By lowering the additional cost of supplying loans in its foreign market, a fall in $\tau$ unambiguously reduces the share of the overall loan volume that a bank supplies to its domestic market. Using this result in the differentiation of the price (6), we find

$$
\frac{\partial R}{\partial \tau}=\frac{-s^{2} \sigma(1+\sigma)^{2}}{\phi \varepsilon}<0 .
$$

Since a fall in $\tau$ redirects a fixed loan volume towards the foreign market, where the probability of success is lower [see eq. (12)], total output falls as a result of this change, raising the price of output and loans.

Effect on bank profits, taxpayers and consumers. Differentiating optimized profits in (13) with respect to $\tau$ and using (35) and (36) gives

$$
\frac{\partial \Pi}{\partial \tau}=-(1-\gamma) L+\frac{s(1+\sigma)}{2 \phi^{2} b \varepsilon}\left[\phi^{2} \sigma \eta+2 s \tau(1+\sigma) \mu\right]
$$

where $\mu(>0)$ is given in (30) and $\varepsilon(>0)$ is defined in (35), while (using $L=E / k$ )

$$
\eta \equiv s(1+\sigma)-b(1+\gamma \sigma) \frac{E}{k} \gtrless 0 .
$$

The first term in (37) gives the direct effect of changing trade costs on the profits of the bank. Through this effect, a fall in $\tau$ raises the bank's profits by making its foreign 
loans less expensive. The second term in (37) captures the effects on profits resulting from the higher share of foreign lending induced by a lower $\tau$ [eq. (35)]. A fall in trade costs will hurt the bank's profits through this second effect, if the foreign market is less profitable than the domestic market. This will be the case when the higher information costs of foreign lending dominate the higher implicit subsidies through the government's deposit insurance, i.e., when $\eta>0$. From (38) this is, in turn, more likely when the governments' regulation policy is strict ( $k$ is high). Conversely, if the regulation policy is lax and $\eta<0$, then the bank will benefit from shifting its lending activities towards the more highly subsidized foreign market, provided that $\tau$ is small in the initial equilibrium. ${ }^{20}$ In this last case, a fall in trade costs $\tau$ unambiguously increases bank profits.

Next, we consider the effects on taxpayers in a country. Differentiating (26), substituting in from (35) and (36) and simplifying gives

$$
\frac{\partial T}{\partial \tau}=(1-k) \frac{s^{2} \sigma(1+\sigma)^{2}}{b \phi \varepsilon}>0 .
$$

As this effect is unambiguously positive, a fall in trade costs reduces tax revenue, in that it increases the subsidy payments from taxpayers to the bank. Lower trade costs increase the share of the bank's lending that is allocated to the foreign country, where monitoring is lower due to higher information costs. Thus, a fall in trade costs results in a larger share of loans being exposed to the higher risk of failure.

Finally, we analyze the effects of a change in $\tau$ on consumer surplus. From (28) we get, with the help of (35) and (36),

$$
\frac{\partial C S}{\partial \tau}=\frac{s^{2} \sigma(1+\sigma)^{2}}{\phi \varepsilon} Q>0 .
$$

This effect is again positive, implying that lower trade costs reduce consumer surplus. Since the overall loan volume does not change, due to the constraint imposed by the binding capital requirement, a fall in $\tau$ affects consumer surplus only through the increased share of lending in the foreign market. The lower success probability of foreign loans means that expected output falls, with a consequent decline in consumer surplus. In comparing the impact of trade integration in (37)-(40), we see that there is a potential conflict between the interests of banks on the one hand and consumers and

\footnotetext{
${ }^{20}$ Note that, from (18), $\tau>0$ unambiguously makes reliance on the home market more profitable.
} 
taxpayers on the other. Trade integration (i.e., a fall in trade costs) will benefit banks, at least when regulation policy is lax ( $k$ is low) and trade costs $\tau$ are low in the initial equilibrium. At the same time, trade integration induces each bank to shift a larger share of its loans to the foreign market, where monitoring levels are lower. This implies higher failure rates for loans, harming both taxpayers and consumers.

Given these conflicting effects, the implications of lower trade costs for welfare in each of the two symmetric countries [eq. (25)] will generally be ambiguous. However, when the welfare weight on bank profits $\left(\beta_{1}\right)$ is sufficiently low, for example because a large share of the banks is owned by residents of third countries, then trade integration will harm both countries in the region. We summarize these results as follows.

Proposition 3 A reduction in the trade costs of cross-border lending $(\tau)$ reduces consumer surplus and raises the expected losses of taxpayers in both countries. When the weight of bank profits in the national welfare functions is sufficiently low, trade integration also reduces aggregate welfare in each country.

Proposition 3 shows that trade integration in the financial sector may have different, and more negative effects, as compared to trade integration in manufacturing or other services. The welfare results in Brander and Krugman (1983) are ambiguous in general but can be signed in two special cases. When trade costs are low, further reductions are welfare improving as the increase in competition yields higher consumer surplus while the increased two-way trade in the identical product is almost costless. The contrast in results arises for two reasons. First, in our model of lending, trade integration cannot expand the overall supply of loans when binding capital requirements are set by regulators, while production expands in Brander and Krugman. Moreover, by incorporating a failure probability that is higher for loans to foreign firms, trade integration increases the aggregate risks in the banking sector which, in our model, are partly shifted onto taxpayers by means of savings deposit insurance. At the same time, banks are likely to welcome trade integration, partly because of the higher implicit subsidies they receive from taxpayers when they expand their foreign lending.

\subsection{Reduced information costs abroad}

We now turn to the effects of a decline in the foreign information cost parameter $\sigma$. As we have argued above, these costs arise primarily from differences in national laws, 
in particular with respect to insolvency, collateral and securities laws. Accordingly, a core example of reduced foreign information costs lies in the coordination, or partial harmonization, of these areas of national law. In the European Union, this coordination represents an important element in the recent capital markets union initiative (see European Commission, 2015a, part 6). Another example comes from the Single Supervisory Mechanism of the European banking union, which aims to harmonize banking standards in EU countries. Increasing the information about the liquidity and solvency of foreign banks is another relevant example of reduced foreign information costs, because a substantial share of lending abroad occurs to foreign financial institutions.

We proceed in the same way as above, but simplify the analysis once again by evaluating the derivatives at $\tau=0$.

Effect on market shares and prices. We differentiate a bank's allocation of loans in (18) with respect to $\sigma$. Evaluating at $\tau=0$ gives

$$
\left.\frac{\partial \gamma}{\partial \sigma}\right|_{\tau=0}=\frac{s\left[(1+\sigma)^{2}+(2 \sigma+1)\right]-4 b L(1+\sigma)}{2 b L\left[(1+\sigma)^{2}+1\right]} \gtrless 0 .
$$

In contrast to a fall in trade costs $\tau$ that unambiguously reduces $\gamma$ [see eq. (35)], a fall in the information costs for lending abroad has an ambiguous effect on the bank's allocation of loans. A lower level of $\sigma$ will reduce the domestic loan share $\gamma$ only when the transaction cost parameter $s$ is large and the capital requirement $k$ is high, implying a low equilibrium loan level from $L=E / k$ [cf. the discussion of eq. (19)]. In this case, a fall in $\sigma$ reduces the cost disadvantage of foreign loans and therefore lowers $\gamma$. In contrast, a fall in $\sigma$ will increase $\gamma$ when the regulation policy is lax and the loan allocation is primarily determined by the higher taxpayer subsidy on foreign loans. The fall in $\sigma$ then reduces this subsidy advantage of foreign loans and raises $\gamma$, shifting lending to the domestic market.

The effect on the price of loans in equilibrium [in (6)] is derived in the appendix and given by

$$
\left.\frac{\partial R}{\partial \sigma}\right|_{\tau=0}=\frac{\phi b L}{\mu}\left[\frac{(1-\gamma)}{(1+\sigma)}-\sigma \frac{\partial \gamma}{\partial \sigma}\right]>0 \Longleftrightarrow \frac{b E}{k}\left[(1+\sigma)^{2}+1+2 \sigma\right]-s \sigma(2+\sigma)>0,
$$

where $\mu>0$ is defined in (30). Equation (42) shows that the direct effect of $\sigma$ on the loan rate is positive, implying that lower information costs for foreign loans reduce the 
loan rate. This is because a smaller $\sigma$ increases the monitoring of foreign loans, raising expected output and lowering its price. The indirect effect is ambiguous and depends on the change in $\gamma$, as given in (41). A sufficient, but not a necessary condition, for the overall effect to be positive is that $\partial \gamma / \partial \sigma<0$ holds. In this case a fall in $\sigma$ will reallocate loans towards the domestic market, where the success probability is higher. Even if $\partial \gamma / \partial \sigma>0$, so that a fall in $\sigma$ shifts lending to the more risky foreign market, a fall in $\sigma$ will still reduce the loan rate when the capital requirement $k$ chosen by the two countries is not too strict in the initial equilibrium ( $k$ is not too high). In the following we assume that this condition is met so that $\partial R / \partial \sigma>0$ holds in (42).

Effect on bank profits, taxpayers and consumers. We again analyze the effects of changes in information costs abroad on the bank, taxpayers and consumers in one of the countries. The impact on the bank's profits is found by differentiating (10), using (41)-(42) to yield:

$$
\frac{\partial \Pi}{\partial \sigma}=\frac{-\phi \eta}{2 b s(1+\sigma)} \frac{\partial R}{\partial \sigma} .
$$

The effect of a fall in $\sigma$ on the bank's profits shows a similar ambiguity to that of a reduction in $\tau$ [see eq. (37)]. When condition (42) holds, the sign of $\partial \Pi / \partial \sigma$ depends once again on the sign of $\eta$, and hence on the importance of higher information costs for foreign loans [as parameterized by $s(1+\sigma)$ in $(38)$ ], relative to the higher implicit subsidy for foreign loans [as captured in the term $b(1+\gamma \sigma) E / k$ in (38)]. When regulation policy is tight and $k$ is large, the first effect dominates and $\eta>0$. In this case the bank profits from the lower information costs of lending abroad. When $k$ is low, however, we get $\eta<0$. In this case, the fall in $\sigma$ increases $\gamma$ from (41), as subsidies for foreign loans are reduced while, at the same time, the bank's profit margins are higher for foreign loans. Hence the bank loses from the reallocation of its lending towards its domestic market.

To obtain the impact on taxpayers, we differentiate (26) and use (42) to get

$$
\frac{\partial T}{\partial \sigma}=\frac{-(1-k)}{b} \frac{\partial R}{\partial \sigma}<0
$$

which is negative when condition (42) holds, implying that taxpayers benefit from a reduction in $\sigma$. Intuitively, since the total lending volume is fixed by the capital requirement, the effect of a lower $\sigma$ on tax revenue depends only on the average share of loans that are successful. Since reduced information costs for foreign loans increase optimal monitoring levels for these loans, risks for taxpayers are reduced and tax revenue rises. 
Finally, differentiating (28) with respect to $\sigma$ yields the effect on consumer surplus:

$$
\frac{\partial C S}{\partial \sigma}=-Q \frac{\partial R}{\partial \sigma}<0
$$

Thus consumers also benefit from lower information costs abroad. The fall in $\sigma$ causes the share of successful loans to rise through increased monitoring of foreign loans. This reduces the loan rate and expands output, translating directly into a positive effect on consumer surplus.

Collecting these effects on the components of national welfare, we see that the benefits of financial integration $d o$ materialize for a reduction in the information costs for foreign loans. We summarize these results as follows:

Proposition 4 If capital regulation is not too strict [condition (42) holds], a reduction in the information costs of cross-border lending, $\sigma$, increases tax revenues and consumer surplus in both countries. If the direct effect of falling information costs dominates for banks $[\eta>0$ holds in (37)], their profits will also rise. National welfare will then increase in both countries for any combination of welfare weights $\left(\beta_{1}, \beta_{2}, \beta_{2}\right)$.

A comparison of Propositions 3 and 4 reveals that the effects of economic integration can be very different, depending on the type of cost to cross-border lending that is lowered. If trade costs for foreign loans are reduced, while the information costs for these loans remain unchanged, then financial integration may have detrimental effects.

This could be the case, for example, in an integrated payments area like the Eurozone, where transaction costs for cross-border lending are further reduced by securitization, but high information costs for foreign loans remain due to nationally diverging laws and regulations. Our analysis therefore suggests that it is essential for such liberalization of financial markets to be accompanied by policy measures that reduce the information costs of lending abroad, such as coordinating national laws that affect the recovery of defaulting loans.

\section{$5 \quad$ Financial integration and optimal regulation}

A final issue in our analysis is how financial integration changes the optimal regulation policy. Specifically, we ask how reductions in the trade cost parameter $\tau$ and the 
Table 1: Reducing transaction costs for foreign loans $(\tau)$

\begin{tabular}{|c|c|c|c|c|c|c|c|c|}
\hline & $\tau$ & $k$ & $\gamma$ & $R$ & $\Pi$ & $T$ & $C S$ & $W$ \\
\hline & & \multicolumn{7}{|c|}{ Case 1: Low welfare weight of tax revenue $\left(\beta_{2}=3\right)$} \\
\hline (1) & $\tau=0.25$ & 0.516 & 0.695 & 7.543 & 6.377 & -0.686 & 3.018 & 7.339 \\
\hline$(2)$ & $\tau=\left.0\right|_{k=\bar{k}}$ & 0.516 & 0.606 & 7.604 & 6.530 & -0.715 & 2.870 & 7.254 \\
\hline$(3)$ & $\tau=0$ & 0.475 & 0.583 & 7.480 & 6.764 & -0.888 & 3.176 & 7.277 \\
\hline & & \multicolumn{7}{|c|}{ Case 2: High welfare weight of tax revenue $\left(\beta_{2}=8\right)$} \\
\hline$(4)$ & $\tau=0.25$ & 0.929 & 0.963 & 8.259 & 5.109 & -0.029 & 1.516 & 6.391 \\
\hline$(5)$ & $\tau=\left.0\right|_{k=\bar{k}}$ & 0.929 & 0.844 & 8.317 & 4.939 & -0.034 & 1.416 & 6.087 \\
\hline (6) & $\tau=0$ & 0.937 & 0.848 & 8.326 & 4.918 & -0.029 & 1.402 & 6.088 \\
\hline
\end{tabular}

Note: Parameters held constant: $E=2, s=10, A=10, b=1, \sigma=0.5, \beta_{1}=\beta_{3}=1$

foreign information cost parameter $\sigma$ affect the optimal, coordinated choice of capital requirement $k$. The determinants of the optimal capital requirement, as discussed in Section 3.2, are too complex, however, to answer this question analytically. We therefore consider some numerical examples that highlight the patterns of optimal responses.

Table 1 reports the results from a first set of numerical simulations that show the effects of reducing the trade cost parameter $\tau$. The table is divided into two cases, corresponding to different values of $\beta_{2}$, the welfare weight on tax revenues. In Case 1 , the weight on tax revenues is relatively low $\left(\beta_{2}=3\right)$ while Case 2 has a higher weight $\left(\beta_{2}=8\right)$. From Proposition 2 this implies a higher capital requirement in the government's optimum in Case 2. Rows (1)-(3) correspond to Case 1 while rows (4)-(6) repeat the same set of exercises for Case 2.

Rows (1) and (4) in Table 1 give the values of the variables of interest in an initial equilibrium with trade costs equal to $\tau=0.25$. Rows (2) and (5) report the effects of a fall in trade costs to $\tau=0$ when the capital requirement is held fixed at its initial level. The resulting changes in equilibrium values thus correspond to our analytical results in Section 4.1, where we have also held capital requirements fixed. Finally, rows (3) and (6) give the equilibrium values for all variables when capital requirements are optimally adjusted to the reduction in $\tau$. In all numerical examples, we have confirmed that the total volume of lending is indeed below the firms' optimized lending volumes in the unconstrained model of Section 3.1. ${ }^{21}$

\footnotetext{
${ }^{21}$ The optimized capital standards fulfill the requirements for an interior solution, $\tilde{k}<k<1$, even
} 
Table 2: Reducing information costs for foreign loans $(\sigma)$

\begin{tabular}{|ll|ccccccc|}
\hline \multicolumn{1}{|c|}{$\sigma$} & $k$ & $\gamma$ & $R$ & $\Pi$ & $T$ & $C S$ & $W$ \\
\hline$(1)$ & $\sigma=0.75$ & 0.762 & 0.533 & 6.971 & 7.198 & -0.216 & 4.588 & 10.706 \\
\hline$(2)$ & $\sigma=\left.0.5\right|_{k=\bar{k}}$ & 0.762 & 0.513 & 6.874 & 7.372 & -0.193 & 4.886 & 11.294 \\
$(3)$ & $\sigma=\left.0.25\right|_{k=\bar{k}}$ & 0.762 & 0.498 & 6.720 & 7.631 & -0.156 & 5.379 & 12.228 \\
$(4)$ & $\sigma=\left.0\right|_{k=\bar{k}}$ & 0.762 & 0.500 & 6.486 & 7.978 & -0.101 & 6.174 & 13.649 \\
\hline$(5)$ & $\sigma=0.5$ & 0.695 & 0.495 & 6.714 & 7.531 & -0.314 & 5.400 & 11.360 \\
$(6)$ & $\sigma=0.25$ & 0.639 & 0.481 & 6.380 & 7.894 & -0.389 & 6.552 & 12.498 \\
$(7)$ & $\sigma=0$ & 0.601 & 0.500 & 6.003 & 8.199 & -0.397 & 7.987 & 14.200 \\
\hline
\end{tabular}

Note: Parameters held constant: $E=3, s=7, A=10, b=1, \tau=0, \beta_{1}=\beta_{3}=1, \beta_{2}=5$.

A first result that emerges from Table 1 is that total welfare does indeed fall following a reduction in $\tau$, and this is true in both Cases 1 and 2. Bank profits rise in Case 1 but fall in Case 2, whereas tax revenues and consumer surplus fall in both cases when the capital requirement remains fixed [rows (2) and (5)]. These results correspond to our findings in Section 4.1, as summarized in Proposition 3. The new result is that the optimal capital requirement falls in Case 1 but rises in Case 2, demonstrating that the endogenous response of $k$ to a reduction in $\tau$ is ambiguous. Intuitively, when the welfare weight of tax revenues is sufficiently low, as in Case 1, the optimal adjustment of $k$ is dominated by the increased profit opportunities of banks resulting from the lower trade costs. Hence the capital requirement is relaxed, in order to increase the total volume of lending. In Case 2, in contrast, where the welfare weight of tax revenues is large, the optimal response is to tighten the capital requirement in order to limit tax revenue losses following the fall in $\tau$. Finally, note that the endogenous response of $k$ does not overturn the negative overall welfare effects caused by the reduction in $\tau$.

We now turn to the effects of reducing the extra information cost of foreign lending, $\sigma$. The results for this set of numerical exercises in given in Table 2. Here we consider only a single case, but reduce $\sigma$ in several steps. Again we report the results when the capital requirement is held fixed at its initial level [rows (2) to (4)], and when it is free to adjust optimally to the changed exogenous conditions [rows (5) to (7)].

Table 2 shows that, in contrast to the reduction in the transaction cost parameter $\tau$, a fall in the foreign information cost parameter $\sigma$ increases profits, tax revenues and con-

though the welfare weights used in the simulations differ from the sufficient conditions in Proposition 1. 
sumer surplus, and thereby increases aggregate welfare when the capital requirement is held fixed. This corresponds to our analytical results in Section 4.2, as summarized in Proposition 4. Moreover, the induced change in the share of domestic lending $\gamma_{i}$ is, indeed, ambiguous. It initially falls below $1 / 2$ and then returns to $1 / 2$ as $\sigma$ is incrementally reduced. Finally, the optimal coordinated capital requirement falls continuously as $\sigma$ falls. The difference in this case to that of the falling trade cost $\tau$, is that the decline in information costs benefits all components of national welfare when the capital requirement is held fixed. As gains to consumers and banks rise more than proportionately as total lending volume increases, whereas losses to taxpayers increase (roughly) linearly, the optimal policy is to reduce $k$ for a wide range of welfare weights $\beta_{2}$.

\section{Conclusion}

In this paper we have set up a two-country model with duopolistic banks that are engaged in cross-border lending. These loans are made to competitive, producing firms and therefore have real effects on the economy. Banks are constrained in their aggregate lending activity by government regulation, but can decide how to allocate the total loan volume between their domestic and the foreign markets, and how strictly they monitor their customers in each country. Banks face limited liability when their loans fail, because their funds partly come from savings deposits that are guaranteed by national governments. This part of the default risk is effectively shifted to taxpayers, causing a moral hazard problem for the banks' monitoring decision and distorting their lending activities towards the foreign market. Governments choose capital requirements so as to maximize domestic welfare, given the exogenous weights they put on the interests of banks, taxpayers and consumers.

In this setting we have analyzed the effects of financial integration on the different agents in our model, as well as on aggregate national welfare. We find that the desirability of integration depends crucially on the type of costs for cross-border lending that are reduced. If financial integration is mainly associated with a fall in trade costs, the monitoring levels for foreign loans cannot be expected to rise. More risky foreign lending may then replace safer domestic lending in equilibrium, with adverse consequences for consumers and taxpayers. On the other hand, if financial integration is driven mainly by a fall in the information costs for foreign loans, then the optimal monitoring of these 
loans will rise and banks, consumers and taxpayers can all be expected to benefit from this financial integration. We conclude that mere reductions in the transactions costs of cross-border lending can be harmful, unless they are accompanied by measures that reduce the information costs specific to foreign lending.

These results are particularly relevant for the European Union, where the introduction of the Euro area has significantly lowered transaction costs for cross-border lending while plans are under way to reduce these costs further in a capital markets union. Our results suggests that it is then essential for the European Union to reduce the information costs of foreign lending at the same time. The Single Supervisory Mechanism of the European banking union represents a step in this direction by harmonizing the standards of financial institutions, among which a substantial part of cross-border lending occurs. Further measures are likely to be needed, however, with national insolvency, collateral and securities laws needing greater international coordination.

Our analysis can be extended in several directions. One possible extension would be to introduce a more complex output sector that is characterized by imperfect competition and some market power vis-à-vis banks in determining the equilibrium loan rate. Another extension would be to incorporate a richer set of government policies. For example, it would be possible to consider policy measures that impact upon foreign lenders alone, say through a special levy on the costs of lending by non-domestic institutions. Equally, governments might negotiate reciprocal access to their domestic markets for foreign banks that would have exactly the opposite effect to this special levy. We leave these extensions to further research. 


\section{References}

Acharya, V. (2003). Is the international convergence of capital adequacy regulation desirable? Journal of Finance 58, 2745-2781.

Acharya, V., Hasan, I., Sauners, A. (2006). Should banks be diversified? Evidence from individual bank loan portfolios. Journal of Business 49, 1355-1412.

Allen, F., Carletti, E., Marquez, R. (2011). Credit market competition and capital regulation. Review of Financial Studies 24, 983-1018.

Beltratti, A., Stulz, R.M. (2012). The credit crisis around the globe: Why did some banks perform better? Journal of Financial Economics 105, 1-17.

Barth, J., Lee, C., Phumiwasana, T. (2006). Deposit insurance schemes. In: Ch. Lee and A. Lee (eds.), Encyclopedia of Finance, 299-306.

Besanko, D., Kanatas, G. (1993). Credit market equilibrium with bank monitoring and moral hazard. Review of Financial Studies 6, 213-232.

Berger, A., Miller, N., Petersen, M., Rajan, R., Stein, J. (2005). Does function follow organizational form? Evidence from the lending practices of large and small banks. Journal of Financial Economics 76, 237-268.

Boot, A., Thakor, A. (2000). Can relationship banking survive competition? Journal of Finance 55, 679-713.

Brander, J., Krugman, P. (1983). A "reciprocal dumping" model of international trade. Journal of International Economics 15, 313-321.

Buch, C., Koch, C.T., Koetter, M. (2011). Size, productivity, and international banking. Journal of International Economics 85, 329-334.

Buch, C., Koch, C.T., Koetter, M. (2013). Do banks benefit from internationalization? Revisiting the market power-risk nexus. Review of Finance 17, 1401-1435.

Claessens, S., van Horen, N. (2014). Foreign banks: Trends and impact. Journal of Money, Credit and Banking 46 (Supplement No.1), s295-s326. 
Committee on the Global Financial System (2010). Long-term issues in international banking. CGFS Papers No. 41. Bank for International Settlements, Basel.

De Blas, B., Russ, K.N. (2013). All banks great, small, and global: Loan pricing and foreign competition. International Review of Economics and Finance 26, 4-24.

De Nicolò, G., Gamba, A., Lucchetta, M. (2012). Capital regulation, liquidity requirements and taxation in a dynamic model of banking. IMF Working Paper 12/72. Washington, D.C.

Degryse, H., Ioannidou, V., Liberti, J.M., Sturgess, J. (2016). When do laws and institutions affect recovery rates on collateral? CEPR Discussion Paper No. 11406. London.

Dell'Ariccia, G., Marquez, R. (2006). Competition among regulators and credit market integration. Journal of Financial Economics 79, 401-430.

Deng, S., Elyasiani, E. (2008). Geographic diversification, bank holding company value, and risk. Journal of Money, Credit and Banking 40, 1217-128.

Diamond, D., Dybvig, P. (1983). Bank runs, deposit insurance, and liquidity. Journal of Political Economy 91, 401-419.

Diamond, D.W., Rajan, R. (2009). The credit crisis: Conjectures about causes and remedies. American Economic Review 99, Papers and Proceedings, 606-610.

Eaton, J. (1994). Cross-border banking. NBER Working Paper No. 4686. Washington, D.C.

European Commission (2015a). Action plan on building a capital markets union. Document $\operatorname{COM}(2015)$ 468. Brussels.

European Commission (2015b). Proposal for a regulation laying down common rules on securitization and creating a European framework for simple, transparent and standardized securitization. Document COM(2015) 472. Brussels.

Francois, J, Hoekman, B. (2010). Services trade and policy. Journal of Economic Literature 48, 642-692. 
Goetz, M., Laeven, L., Levine, R. (2016). Does the geographic expansion of bank assets reduce risk? Journal of Financial Economics 120, 346-362.

Haufler, A., Maier, U. (2016). Regulatory competition in capital standards with selection effects among banks. CESifo Working Paper No. 5839. Munich.

Haufler, A., Wooton, I. (2010). Competition for firms in an oligopolistic industry. The impact of economic integration. Journal of International Economics 80, 239-248.

Hellman, T., Murdock, K., Stiglitz, J. (2000). Liberalization, moral hazard in banking, and prudential regulation: Are capital requirements enough? American Economic Review 90, 147-165.

Kind, H.J., Midelfart, K.H., Schjelderup, G. (2005). Corporate tax systems, multinational enterprises, and economic integration Journal of International Economics 65, 507-521.

Lehner, M., Schnitzer, M. (2008). Entry of foreign banks and their impact on host countries. Journal of Comparative Economics 36, 430-452.

Niepmann, F. (2015). Banking across borders. Journal of International Economics 96, 244-265.

Ongena, S., Popov, A., Udell, G. (2013). "When the cat's away the mice will play": Does regulation at home affect bank risk-taking abroad? Journal of Financial Economics 108, 727-750.

Ottaviano G., van Ypersele, T. (2005). Market size and tax competition. Journal of International Economics 6r, 25-46.

Portes, R., Rey, H. (2005). The determinants of cross-border equity flows. Journal of International Economics 65, 269-296.

Portes, R., Rey, H., Oh, Y. (2001). Information and capital flows: The determinants of transactions in financial assets. European Economic Review 45, 783-796.

Rochet, J.-Ch. (1992). Capital requirements and the behaviour of commercial banks. European Economic Review 36, 1137-1178.

Sinn, H.W. (1997). The selection principle and market failure in systems competition. Journal of Public Economics 66, 247-274. 


\section{Appendix}

\section{Derivation of equation (30)}

Differentiating (3) and using $R_{i}=P_{i}$ from (5) gives

$$
\begin{aligned}
\left.\frac{\partial R_{i}}{\partial k}\right|_{\tau=0}=-b & {\left[\frac{\gamma_{i} L_{i}}{s}\left(\frac{\partial R_{i}}{\partial k}+1\right)+q_{i i} L_{i} \frac{\partial \gamma_{i}}{\partial k}+q_{i i} \gamma_{i} \frac{\partial L_{i}}{\partial k}\right.} \\
+ & \left.\frac{\left(1-\gamma_{j}\right) L_{j}}{s(1+\sigma)}\left(\frac{\partial R_{j}}{\partial k}+1\right)-q_{i j} L_{j} \frac{\partial \gamma_{j}}{\partial k}+q_{i j}\left(1-\gamma_{j}\right) \frac{\partial L_{j}}{\partial k}\right] .
\end{aligned}
$$

Using the symmetry assumption adopted in the paper, $R=R_{i}=R_{j}, \gamma=\gamma_{i}=\gamma_{j}$ and $L=L_{i}=L_{j}$. Cancelling terms gives

$$
\left.\frac{\partial R}{\partial k}\right|_{\tau=0}=\frac{b L}{\mu}\left[(1+\gamma \sigma)\left(\frac{\phi}{k}-1\right)-\phi \sigma \frac{\partial \gamma}{\partial k}\right]
$$

where $\phi$ and $\mu$ are defined in (16) and (30). Substituting $\partial \gamma / \partial k$ from (29) and substituting out for $\gamma$ using (18) gives eq. (30) in the main text.

\section{Derivation of equation (42)}

Differentiating (6) with respect to $\sigma$ gives in a first step

$$
\left.\frac{\partial R_{i}}{\partial \sigma}\right|_{\tau=0}=b\left[\frac{\left(1-\gamma_{j}\right) L_{j} \phi}{s(1+\sigma)^{2}}-\frac{\gamma_{i} L_{i}}{s} \frac{\partial R_{i}}{\partial \sigma}-q_{i i} L_{i} \frac{\partial \gamma_{i}}{\partial \sigma}-\frac{\left(1-\gamma_{j}\right) L_{j}}{s(1+\sigma)} \frac{\partial R_{j}}{\partial \sigma}+q_{i j} L_{j} \frac{\partial \gamma_{j}}{\partial \sigma}\right] .
$$

Using symmetry and collecting terms gives

$$
\left.\frac{\partial R}{\partial \sigma}\right|_{\tau=0}=\frac{\phi b L}{\mu}\left[\frac{(1-\gamma)}{(1+\sigma)}-\sigma \frac{\partial \gamma}{\partial \sigma}\right]
$$

which corresponds to the first part of eq. (42) in the main text. Substituting in $\partial \gamma / \partial \sigma$ from (41) and using

$$
\frac{(1-\gamma)}{(1+\sigma)}=\frac{2 b L(1+\sigma)-s \sigma}{2 b L\left[(1+\sigma)^{2}+1\right]}
$$

from (18), gives

$$
\left.\frac{\partial R}{\partial \sigma}\right|_{\tau=0}=\frac{\phi(1+\sigma)}{\mu\left[(1+\sigma)^{2}+1\right]^{2}}\left\{b L\left[(1+\sigma)^{2}+1+2 \sigma\right]-s \sigma(2+\sigma)\right\} .
$$

From (A.2) follows the condition for $\partial R / \partial \sigma>0$ in eq. (42). 